\title{
Estimation of Water Losses Through Evapotranspiration of Water Hyacinth (Eichhornia crassipes)
}

\author{
Dilyan Sasaqi $^{*}$, Pranoto $^{2}$ and Prabang Setyono ${ }^{2}$ \\ ${ }^{1}$ Magister Student of Environmental Science, Universitas Sebelas Maret, Surakarta, Indonesia, \\ ${ }^{2}$ Department of Environmental Science, Postgraduate, Universitas Sebelas Maret, Surakarta, Indonesia
}

${ }^{*}$ Corresponding author: dilyansasaqi16@gmail.com

\begin{abstract}
Batujai Reservoir locates in Batujai Village, West Praya, Central Lombok, West Nusa Tenggara. It is the primary source of irrigation water supply for agriculture in Central Lombok District with an area of around 3,235 ha. The problem is the bloom of water hyacinth weed (Eichhornia crassipes), which can cause reservoir water loss through evapotranspiration, affecting the amount of water reservoir available for the dry season. The objective was to identify the area of cover and estimate water loss through water hyacinth evapotranspiration for the period 2013 - 2017. This study used a descriptive method by analysis of secondary data which were meteorological data and landsat- 8 satellite imagery. Evapotranspiration analyzes use CROPWAT 8.0 , monitoring water hyacinth cover using landsat-8 satellite imagery processed using ENVI 5.3 and ArcGIS 10.4 software. The results show that the spatial distribution of water hyacinth can be detected and mapped accurately with an overall classification accuracy of $84.11 \%-97.04 \%$ using Landsat 8 data, with a kappa coefficient of $0.80-0.96$. The area of water hyacinth cover ranges from $38,400 \mathrm{~m}^{2}-2,158,500 \mathrm{~m}^{2}$, with a cover area of more than $20 \%$, causing water loss above 8,000 $\mathrm{m}^{3}$ day $^{-1}$, which occurred in April 2013, April 2015, April 2016, February 2015, May 2014, May 2016 and July 2016, in those months it was seen that the amount of water loss was greater. Therefore, it is needed to suppress the growth of water hyacinth, in maintaining reservoir water storage capacity to support a systems of sustainable agriculture.
\end{abstract}

Keywords: Batujai Reservoir, evapotranspiration, water hyacinth, water losses

Cite this as: Sasaqi, D., Pranoto, \& Setyono, P. (2019). Estimation of Water Losses Through Evapotranspiration of Water Hyacinth (Eichhornia crassipes). Caraka Tani: Journal of Sustainable Agriculture, 34(1), 86-100. doi: http://dx.doi.org/10.20961/carakatani.v34i1.28214

\section{INTRODUCTION}

Water is the most important resource on earth, it is essential for human beings, economic development, biodiversity, agricultural, industry and domestic use (Laaboudi et al., 2012; Thamaga and Dube, 2018). One of the sources of water in Central Lombok is the Batujai Reservoir, located in Batujai Village, West Praya, Central Lombok Regency, West Nusa Tenggara Province, built in 1977 - 1982 with a variation of the water depth of 6-8 m, inundation area of 890 ha (Rahim and Soeprobowati, 2019). Has a gross capacity of 25 million $\mathrm{m}^{3}$, effective capacity reaches $23.5 \cdot 10^{6} \mathrm{~m}^{3}$ (Yasa et al., 2018) and minimum capacity reaches $1.4 \cdot 10^{6} \mathrm{~m}^{3}$. There are several main rivers that flow into the Batujai Reservoir, including the Leneng River, Tiwubare River and Sringangga River.

The main objective of the Batujai Reservoir construction is to accommodate excess water in the rainy season and be used periodically to irrigate agricultural land in several villages including Penujak, Setanggor, Darek, Ungga, Ranggagata and other villages around West Praya Sub-District with an area of 3,350 ha

\footnotetext{
* Received for publication February 25, 2019 Accepted after corrections April 7, 2019
} 
(Kalih et al., 2018). Another function of the Batujai Reservoir is as a provider of drinking water for Central Lombok district at 60 liters second $^{-1}$ (Achmad, 2011), flood control, power generation, fisheries (Manan, 2018) and as a green open space as a tourist destination (Saputra, 2018).

There is a problem every year in the waters of the Batujai Reservoir, one of which is the hyacinth bloom in almost $30 \%$ of the reservoir area (Achmad, 2011). Water hyacinth (Eichhornia crassipes (Mart.) Solms), is a tropical species belonging to the Pontederiaceae family (Ndimele et al., 2011; Gichuki et al., 2012; Marlin et al., 2013), free floating and rooted forms, perennial aquatic plant originated from Amazon river basin in South America (Sindhu et al., 2017), relies on asexual reproduction, vegetatively through the formation of stolons and also reproduced sexually through seeds (Adeyemi and Osubor, 2016; Yu et al., 2019). Rapid reproduction of water hyacinth making these weeds difficult to control. Water hyacinth can survive in a waters for six years and has a high ability to grow in highly polluted water to assimilate nutrients, metal ions and organic pollutants (Wang and Calderon, 2012; Wang et al., 2012; Su et al., 2018).

Water hyacinth has a variety of adverse effects, including creating anoxic conditions on the lake, thus increasing the level of toxicity and disease (Güereña et al., 2015), blocking water canals (Ndimele et al., 2011), interference lake navigation (Tumbare, 2008), ecosystem destruction, increase in mosquito population (Sanmuga Priya and Senthamil Selvan, 2017; Sindhu et al., 2017), threats to the functioning and biodiversity of aquatic ecosystems, fisheries (Attermeyer et al., 2016), interference in irrigation systems (Opande et al., 2004), increased sedimentation (Bordoloi et al., 2015) and leading to increased water loss through evapotranspiration (ET) relative to normal, open water evaporation (Villamagna and Murphy, 2010; Arp et al., 2017).

Water loss due to water hyacinth can reach three times greater than the natural evaporation rate of water surface that does not have water hyacinth (Osmond and Petroeschhevsky, 2013). Other studies, evaporation of open water averaged $4.3 \mathrm{~mm} \mathrm{day}^{-1}$ and evapotranspiration of aquatic plants an average of $7.8 \mathrm{~mm}$ day $^{-1}$ (Stan et al., 2016). Increased water loss through evapotranspiration of water hyacinth is considered one of the most crucial weed problems in water bodies. Estimating reference evapotranspiration (ETo) has an important role in various aspects of research, such as the hydrological cycle, irrigation system, water resource management (Hou et al., 2013; Berti et al., 2014; Valipour, 2015; Zhao et al., 2015; Abdullahi and Elkiran, 2017; Zhang et al., 2018; Zhang et al., 2019), forest meteorology (Khoshravesh et al., 2015), flood risk assessment, drought analysis, environmental studies (Pandey et al., 2016; Čadro et al., 2018), as a model of assessment and climate change scenarios (Güler, 2014), economical allocation of water resources, increase of water use efficiency (Singh Rawat et al., 2019).

Based on this description, estimating water loss through evapotranspiration of water hyacinth is very important for develop effective water resources regulation and management (Yang et al., 2011; Farg et al., 2012; Lingling et al., 2013; Longobardi and Villani, 2013; Elnmer et al., 2019) to support a system of sustainable agriculture. This study aims to determine water hyacinth evapotranspiration rate, areas and percentage of water hyacinth cover; and water loss due to evapotranspiration of water hyacinth in the Batujai Reservoir, Central Lombok Regency, West Nusa Tenggara, Indonesia.

\section{MATERIALS AND METHOD}

\section{Study area}

This study is conducted at Batujai Reservoir located in Batujai Village, West Praya Sub District, Central Lombok Regency, West Nusa Tenggara Province that lies between $116^{\circ} 15^{\prime} 30^{\prime}$ ' to $116^{\circ} 17^{\prime} 0^{\prime \prime}$ East Longtitude and $08^{\circ} 42^{\prime} 30^{\prime \prime}$ to $08^{\circ} 45^{\prime} 0^{\prime}$ ' South Latitude (Figure 1), this study was carried out in February until March 2018.

\section{Meteorological data}

Meteorological data used was collected from the Kediri Meteorology, Climatology and Geophysics Agency, West Nusa Tenggara, Indonesia. Data on air temperature $\left({ }^{\circ} \mathrm{C}\right)$, relative humidity $(\%)$, wind speed $\left(\mathrm{m} \mathrm{s}^{-1}\right)$ and sunshine (\%) from 2013 - 2017.

\section{Crop coefficient $(\mathrm{Kc})$}

Crop coefficient $(\mathrm{Kc})$ is defined as the ratio of crop potential and vegetation reference evapotranspiration, which is representative of crop specific evaporation parameters (albedo, thermal emissivity, aerodynamic resistance, 
minimum surface resistance) for the various phenological stages. Crop coefficient value of water hyacinth is 1.1 (light to moderate wind) and 1.15 (strong wind) (Dooenboss and Pruitt, 1992).

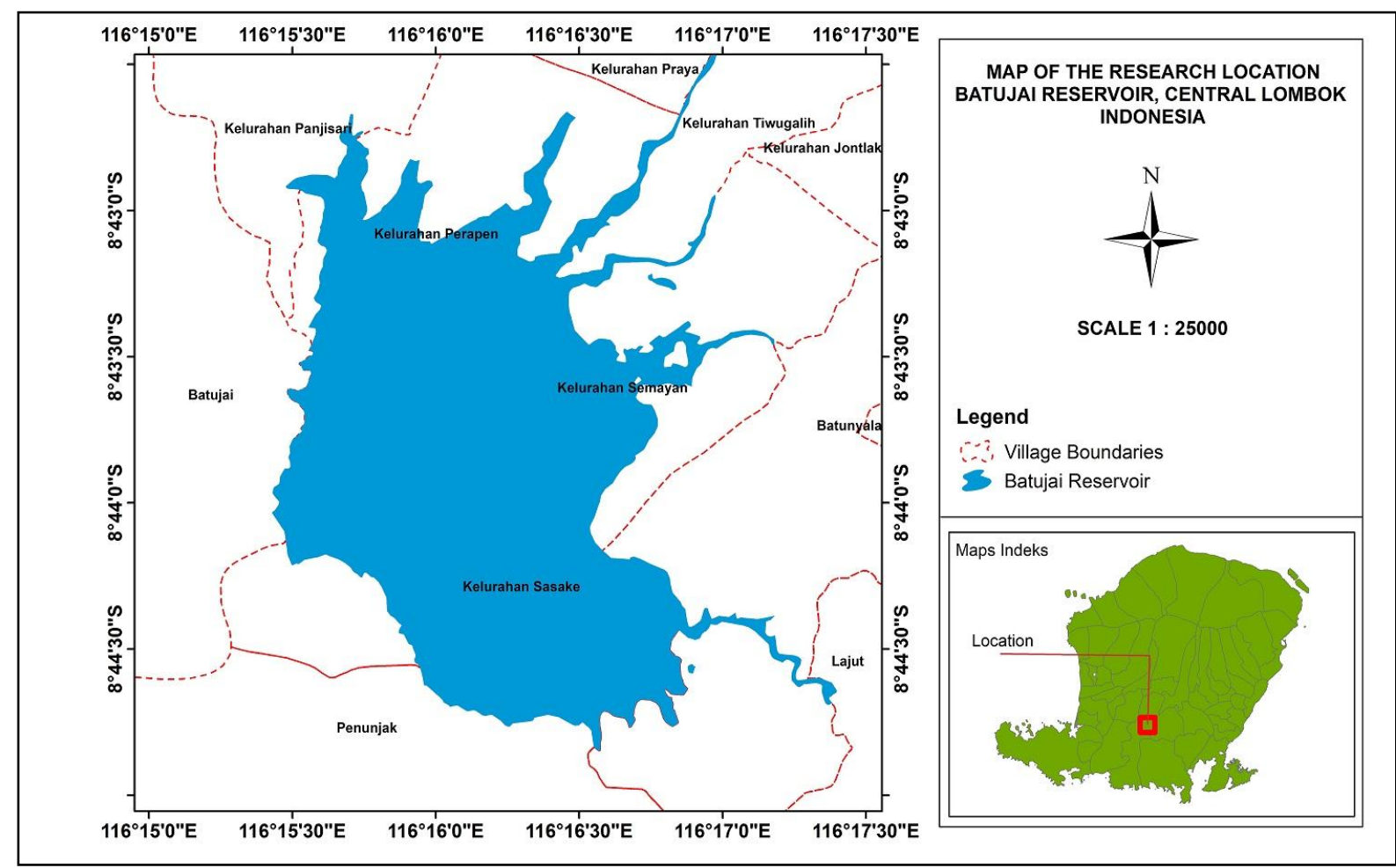

Figure 1. Map of the research location of Batujai Reservoir

\section{Satellite imagery analysis}

Landsat -8 satellite imagery of Batujai Reservoir located at Path 116 and Row 066 obtained from the website https://glovis.usgs.gov. The image acquired during dates from January 2013 to December 2017, satellite imagery selection from 2013-2017 was determined by considering cloud cover $<50 \%$ and satellite images are selected that there is no cloud cover in the reservoir area, 19 satellite imagery were used to analyze surface cover of water hyacinth that represents the rainy season and the dry season.

Data processing is done to determine the boundaries and surface area of the reservoir. The stages of the activity consisted of normalizing data, making RGB composite images, sharpening composite images, delineating lake water surface limits, calculating Reservoir water surface area and analyzing changes in lake water surface area (Indonesian National Institute of Aeronautics and Space, 2015). Using the NDVI index to highlight plants (weeds), at each date with the equation (1) as follows (Ali and El-Din Khedr, 2018).
Normalized Difference Vegetation Index (NDVI) $=\frac{(\text { Band } 5-\text { Band } 4)}{(\text { Band } 5+\text { Band } 4)}$

Identification of water hyacinth is determined using RGB composite image ( $\mathrm{R}=\mathrm{NIR}+\mathrm{SWIR}$, $\mathrm{G}=$ NIR, B = NIR-Red) or composite image of RGB 562 (Suwargana, 2010; Dube et al., 2017) and analyzed by supervised classification methods using ENVI 5.3 software and ArcGIS 10.4. The reservoir boundary is determined by considering the presence of water hyacinth on the water surface, where the vegetation above the water level of the reservoir is part of the surface area of the reservoir (Indonesian National Institute of Aeronautics and Space, 2015)

\section{Calculation of evapotranspiration and crop evapotranspiration (ETc)}

Reference evapotranspiration (ETo) calculated by the FAO Penman - Monteith method, using decision support software - CROPWAT 8.0 developed by FAO (Surendran et al., 2015) and average daily of water losses of evapotranspiration (ETc) for water hyacinth is 
calculated by equation (2) as follows (Rashed, 2014).

$\mathrm{ETc}=\mathrm{ETo} \times \mathrm{Kc}$

Where ETc is crop evapotranspiration in $\mathrm{mm}$ day $^{-1}$, ETo is reference evapotranspiration in $\mathrm{mm}$ day $^{-1}$ and $\mathrm{Kc}$ is crop coefficient.

\section{Estimated water losses due to evapotranspiration of water hyacinth}

Estimated volume of water lost due to open water evapotranspiration of aquatic plants is calculated using the following equation (3) as follows (Rashed, 2014).

Reach water loss $=($ reach ETc reach surface area $)$
Where reach water loss is in $\mathrm{m}^{3}$, reach surface area is in $\mathrm{m}^{2}$ and ETp or ETc is in $\mathrm{mm} \mathrm{day}^{-1}$.

\section{RESULTS AND DISCUSSION}

\section{Areas and percentages of water hyacinth using satellite imagery}

In Batujai Reservoir, water hyacinth is the most common type of floating weed and is a major problem every year, the cover of water hyacinth on the reservoir water surface of the reservoir area. The results of the analysis of 19 Landsat 8 satellite imagery, available for the areas of water hyacinth in the Batujai Reservoir during the period January 2013 to December 2017 are shown in Figure 2.

0.001

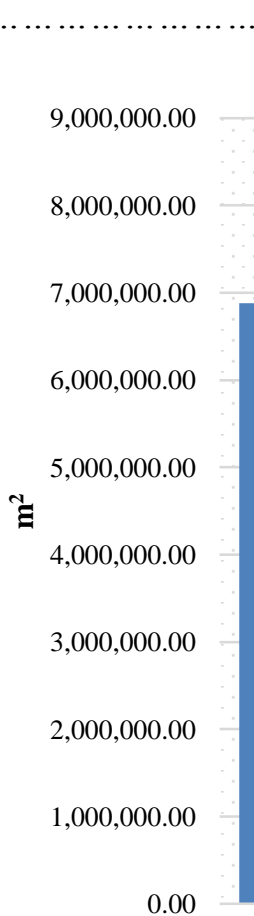

0.00

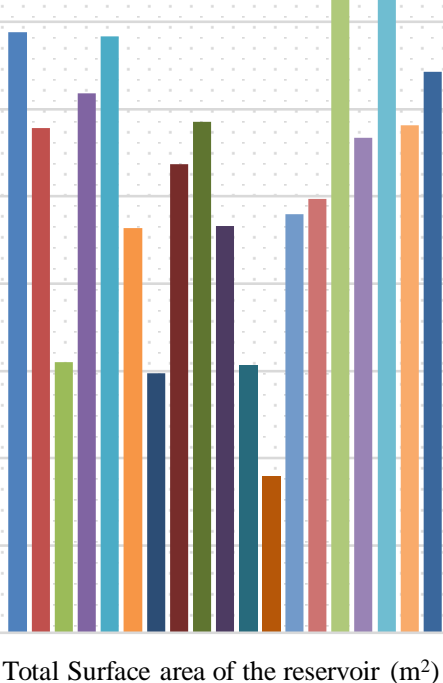

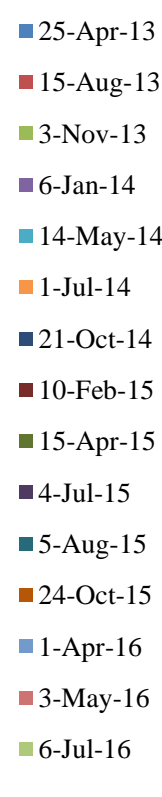

Cover area of the reservoir $\left(\mathrm{m}^{2}\right)$

Figure 2. Cover areas of water hyacinth and surface area of Batujai Reservoir

The total area of water hyacinth cover ranges from $38,400 \mathrm{~m}^{2}-2,158,500 \mathrm{~m}^{2}$ of the total water surface area in the Batujai reservoir which is equivalent to a percentage ranging from $1.28 \%$ $29.61 \%$. The highest cover of water hyacinth was recorded on July 6, 2016 and the lowest was on October 21, 2014. The percentages of the water hyacinth cover area are shown in Figure 3.

The lowest percentage of water hyacinth cover occurred on October 21, 2014 and the highest percentage of water hyacinth cover occurred on May 3, 2016. The percentage of water hyacinth cover in April during the period of 2013 - 2017 tends to have a coverage area of over $20 \%$ that occurred in 2013, 2015 and 2016, while in 2017 the water hyacinth cover area decreased with a coverage area of $14.92 \%$. In May, showed that water hyacinth cover in 2014 and 2016 had a coverage area of more than $20 \%$, while in 2017 , the water hyacinth cover area decreased with a coverage area of $7.16 \%$.

In July, it showed that water hyacinth cover in 2014, 2015, had a cover area of under $10 \%$. During 2016, the area of water hyacinth cover 
increased with a coverage area of $19.60 \%$. The area of water hyacinth cover with an area of cover below 10\% also occurred in August in 2013, 2015 and 2017. In October, it was shown that water hyacinth cover in 2014,2015 , had a cover area of under $10 \%$. During 2016, the area of water hyacinth cover increased with a coverage area of $16.53 \%$.

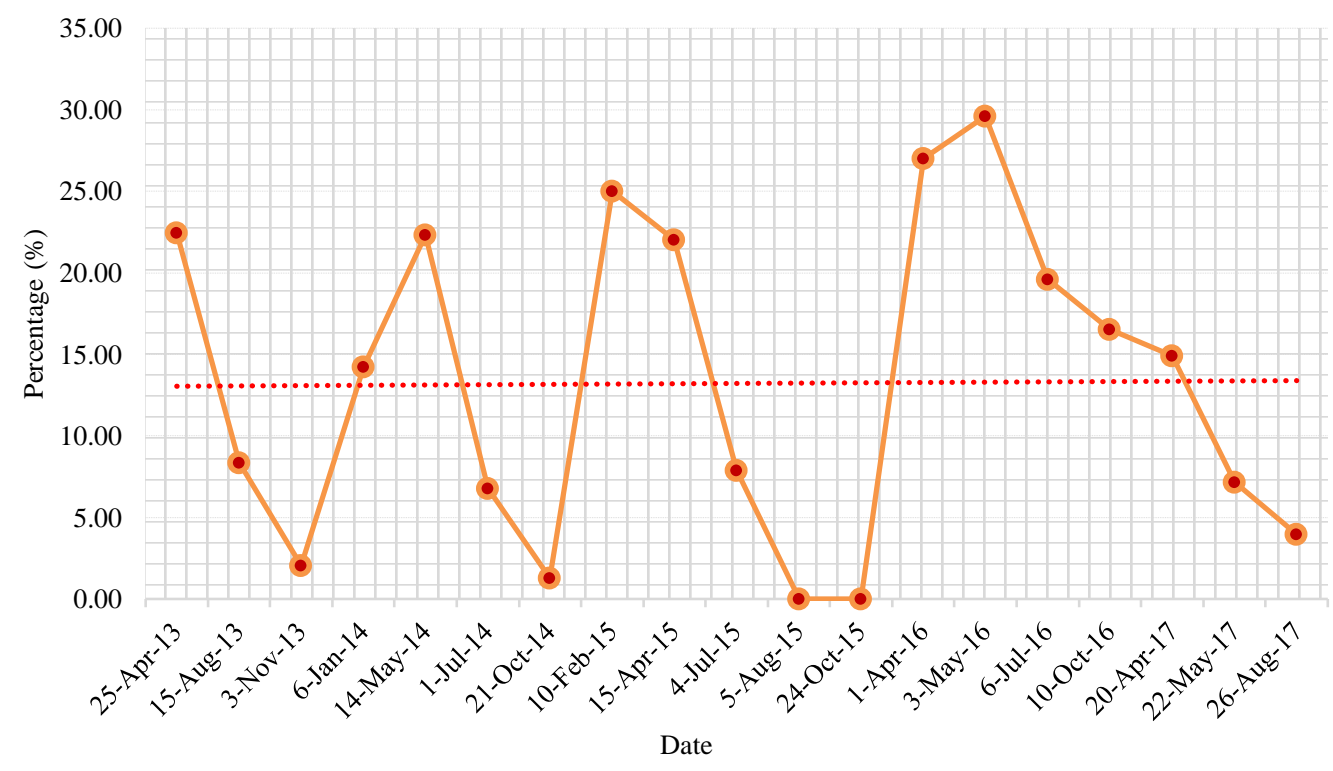

Figure 3. Percentage of water hyacinth cover in the Batujai Reservoir

Figure $4 \mathrm{a}-\mathrm{h}$ shows the spread of water hyacinth in the Batujai Reservoir in Rainy and dry season. In most parts of Indonesia, including Lombok Island, the occurrence of the rainy season in the months of December - January - February and the dry season around the months of June July - August (Yuliana et al., 2015). Previous results (Figure 2) show that the highest water hyacinth cover occurred in July 2016. According to Ali and El-Din Khedr (2018) the highest infestation of water hyacinth occurs in the summer due to the availability of weed growth factors that help water weeds explosion (Rashed, 2014), nutrient absorption is thought to occur varies based on season, with greater absorption in summer when temperatures are higher and more favorable for plant growth (Villamagna and Murphy, 2010). 

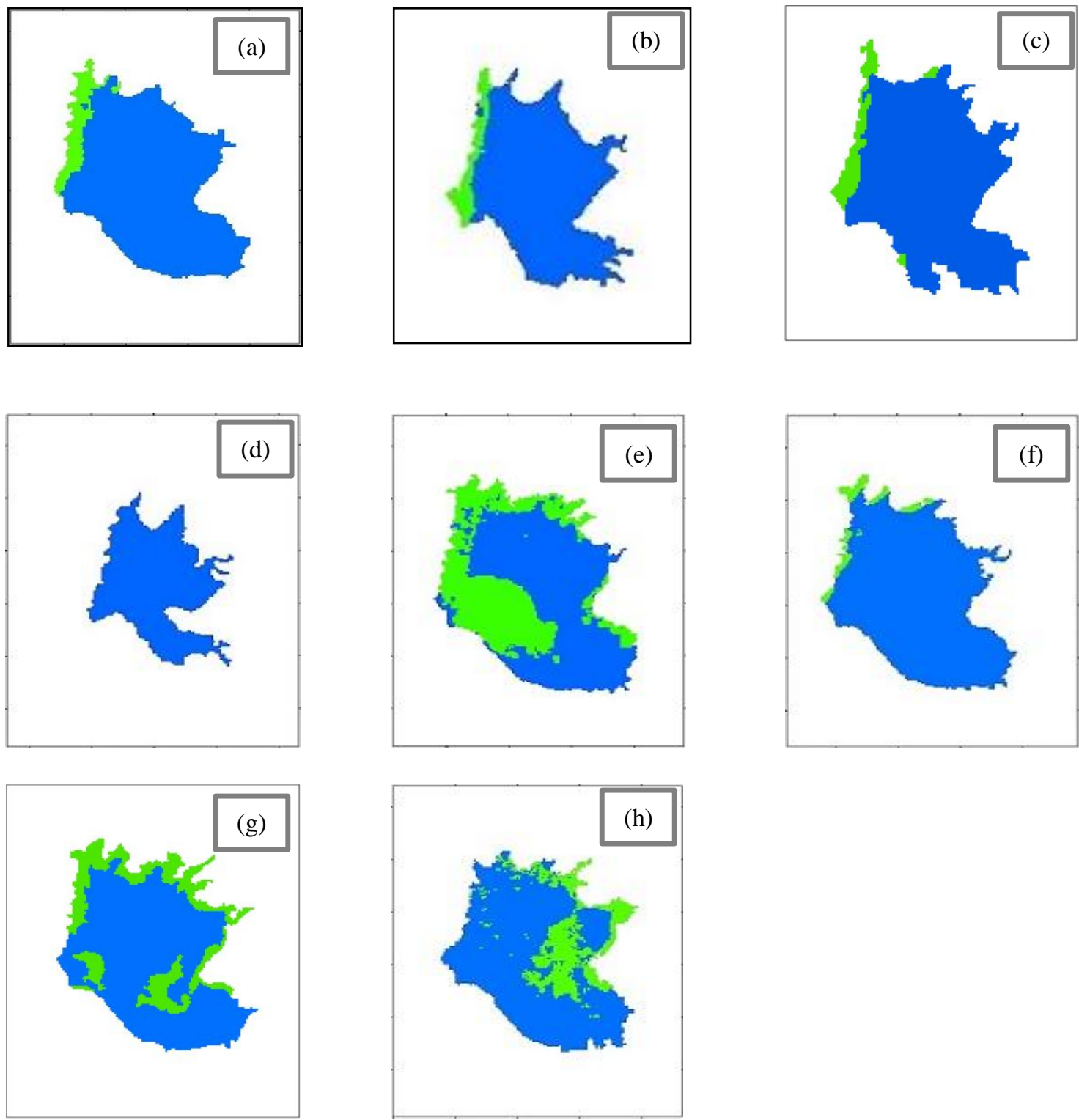

Figure 4. Dry season in (a) August 15, 2013, (b) July 1, 2014, (c) July 4, 2015, (d) August 5, 2015, (e) July 6, 2016, (f) August 26, 2017. Rainy Season in (g) January 6, 2014, (h) February 2015

Figure $5 \mathrm{a}-1$ shows the spread of water hyacinth in the Batujai Reservoir during the transition season in September - October November and March - April - May. The area of water hyacinth cover ranges from $38,400 \mathrm{~m}^{2}-$ $2,090,600 \mathrm{~m}^{2}$, the highest area of water hyacinth cover occurred in May 2016, it is seen the trend of covering water hyacinth more widely during the transition season in March - April - May, compared to the transition month of September October - November. 

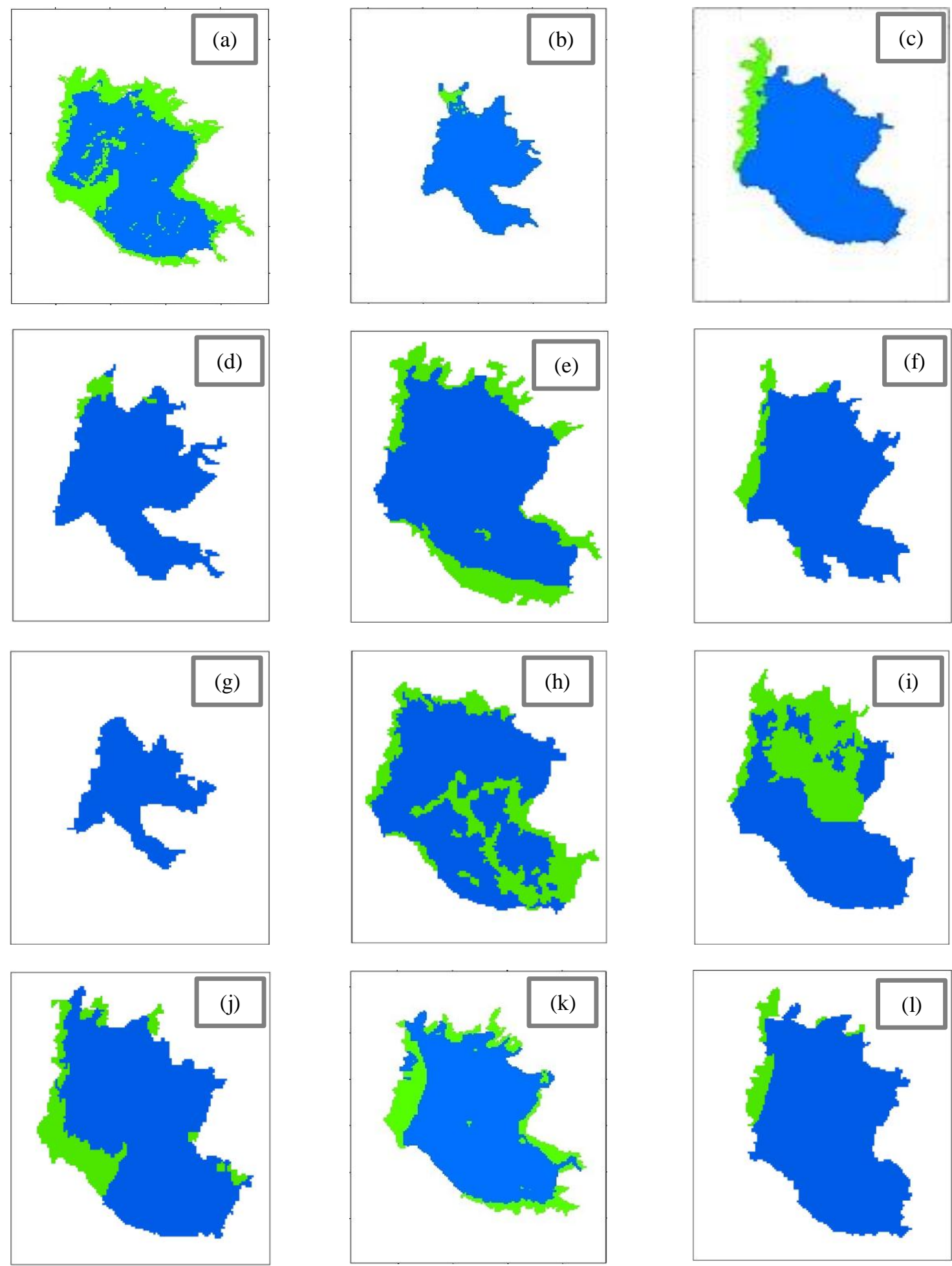

Figure 5. Transition season (a) April 25, 2013, (b) November 3, 2013, (c) May 14, 2014, (d) October 21, 2014, (e) April 15, 2015, (f) October 24, 2015, (f) July 4, 2015, (g) October 24, 2015, (h) april 1, 2016, (i) May 3, 2016, (j) October 10, 2016, (k) April 20, 2017, (l) May 22, 2017. 


\section{Water losses due to water hyacinth evapotranspiration}

Water resources, which are strongly influenced by the hydrological cycle, play a key role in economic and social development (Falamarzi et al., 2014). Figure 6 shows the results of calculation of reference evapotranspiration
(ETo), the highest ETo occurred in October 2014 at $5.60 \mathrm{~mm}_{\text {day }^{-1}}$ and the lowest ETo occurred in June 2013 at $3.27 \mathrm{~mm}$ day $^{-1}$. Reference evapotranspiration (ETo) integrates climatic data such as net radiation, vapor pressure, air humidity, wind speed, air temperature and solar radiation (Paca et al., 2019; Pokhrel et al., 2019).

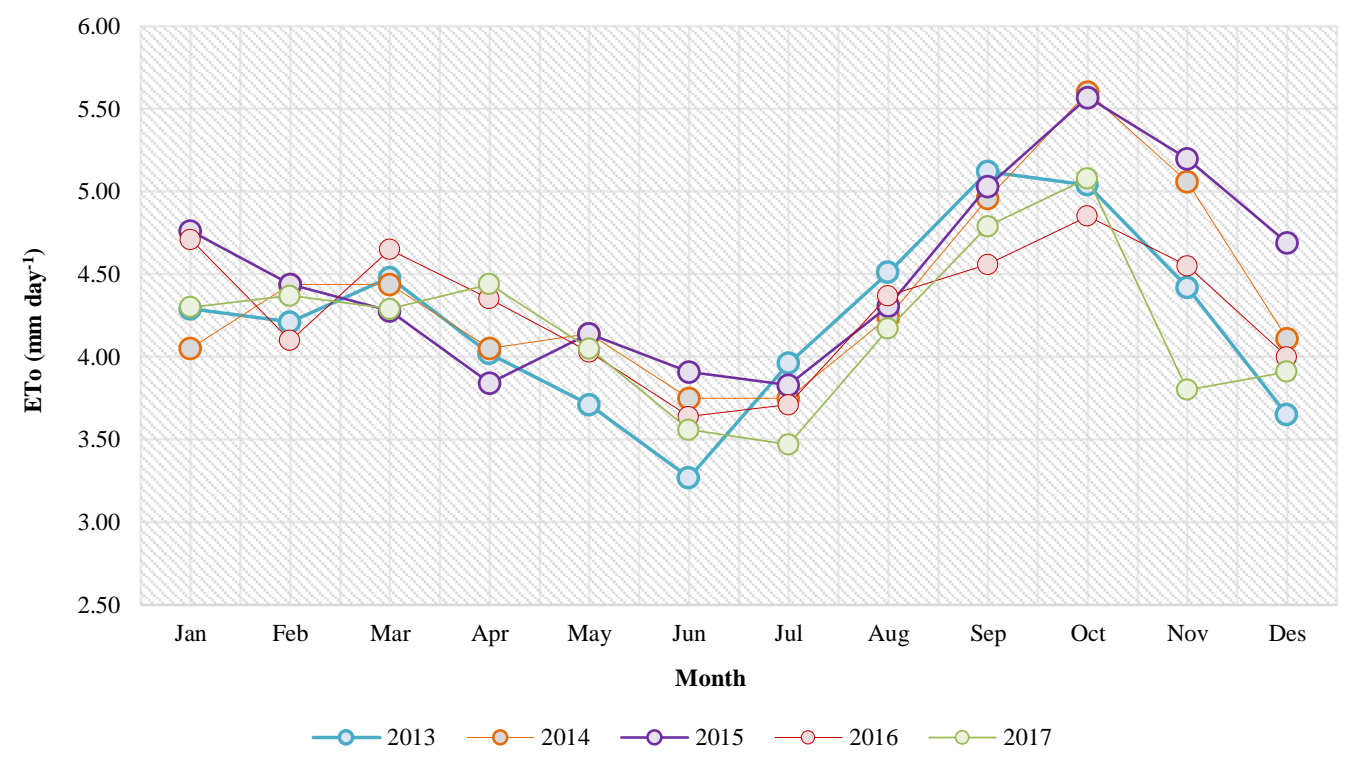

Figure 6. Average monthly reference evapotranspiration from $2013-2017$

There is a similar trend in the level of evapotranspiration every year from 2013 to 2017 , where the level of evapotranspiration tends to be lower in June and July. Then, the rate of evapotranspiration gradually increased in August to reach its highest point in October. June - July August is the dry season in West Nusa Tenggara, this certainly affects the level of evapotranspiration. The rate of evapotranspiration gradually decreased in November - December 2013 - 2017, in January - February the rate of evapotranspiration was in the range of $4.10 \mathrm{~mm}$ day $^{-1}-4.71 \mathrm{~mm} \mathrm{day}{ }^{-1}$, then gradually decreased in May - June which was a transition period in West Nusa Tenggara.
Figure $7 \mathrm{a}-\mathrm{d}$ show weather parameter during 2013 - 2017, the highest monthly air temperature occurs in November 2015 at $28^{\circ} \mathrm{C}$, the lowest occurs in July 2015 at $24.4^{\circ} \mathrm{C}$. The highest monthly relative humidity occurs in February at 88\%, the lowest occurred in August to September 2013 and October 2014, with a value of 77\%. The highest monthly wind speed was in September 2015 at $4.1 \mathrm{~m} \mathrm{~s}^{-1}$, the lowest occurs in June at 0.5 $\mathrm{m} \mathrm{s}^{-1}$. The highest monthly sunlight is $91 \%$ which occurred in October 2013 and October 2014, while the lowest value occurred in December at $40 \%$. 

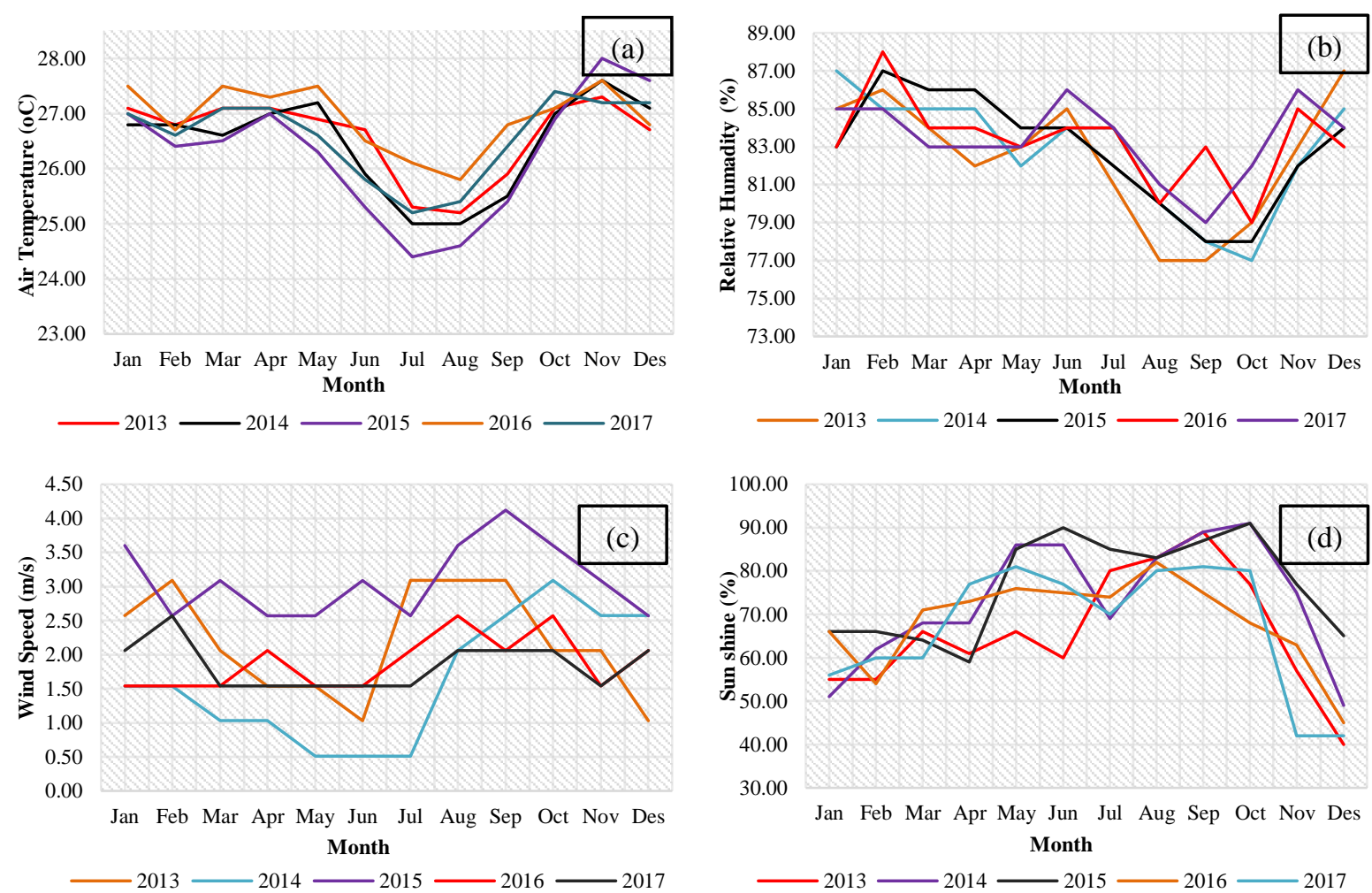

Figure 7. Average monthly weather parameters for the average period of 2013-2017, (a) Air temperature $\left({ }^{\circ} \mathrm{C}\right)$, (b) Relative humidity $(\%)$, (c) Wind speed $\left(\mathrm{m} \mathrm{s}^{-1}\right)$, (d) Sunshine (\%).

Figure 8 presents the results of calculation of water hyacinth evapotranspiration rates from 2013 - 2017. The highest monthly evapotranspiration occurred in October 2014 at 6.16 $\mathrm{mm} \mathrm{day}^{-1}$ and the lowest occurred in June 2013 at
$3.60 \mathrm{~m} \mathrm{day}^{-1}$. According to Ali and El-Din Khedr (2018) that the average evapotranspiration rate of water hyacinth is 2.3 times greater than evaporation of free surface in the same area.

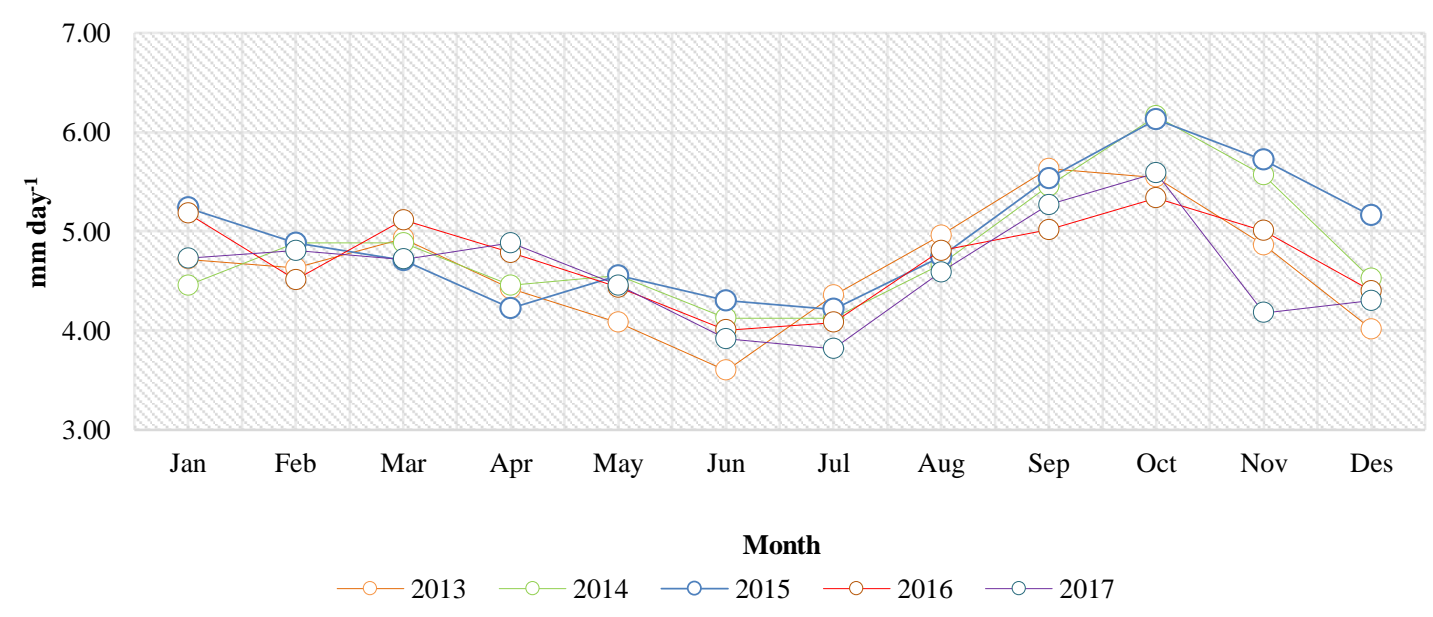

Figure 8. Average monthly evapotranspiration of hyacinth from $2013-2017$.

The relationship between weather factors and the level of evapotranspiration in the Batujai reservoir is carried out by modeling using the regression test presented in Table 1. 
Table 1. Regression Analysis

\begin{tabular}{ccc}
\hline Year & Coefficient of Determination & Regression Equations \\
\hline 2013 & 0.848 & $\mathrm{Y}=3.830+0.503 \mathrm{~T}-0,161 \mathrm{RH}+0,449 U_{2}-0,011 \mathrm{~S}$ \\
2014 & 0.840 & $\mathrm{Y}=4.046+0.230 \mathrm{~T}-0,079 \mathrm{RH}+0,268 U_{2}+0,005 \mathrm{~S}$ \\
2015 & 0.858 & $\mathrm{Y}=1.726+0.363 \mathrm{~T}-0.097 \mathrm{RH}+0.308 U_{2}+0.005 \mathrm{~S}$ \\
2016 & 0.567 & $\mathrm{Y}=10.753+0.561 \mathrm{~T}-0.014 \mathrm{RH}+0.508 U_{2}+0.003 \mathrm{~S}$ \\
2017 & 0.934 & $\mathrm{Y}=3.571+0.452 \mathrm{~T}-0.075 \mathrm{RH}+0.501 U_{2}+0.016 \mathrm{~S}$ \\
\hline
\end{tabular}

Note: $\mathrm{T}=$ Temperature $\left({ }^{\circ} \mathrm{C}\right), \mathrm{RH}=$ Relative Humadity $(\%), U_{2}=$ Wind Speed $\left(\mathrm{m} \mathrm{s}^{-1}\right), \mathrm{S}=$ Sunshine $(\%)$.

The coefficient of determination $\left(\mathrm{R}^{2}\right)$ is used for judging the goodness of fit in a linear regression model. The $\mathrm{R}^{2}$ is based on the proportion of variability of the study variable that can be explained through the knowledge of a given set of explanatory variables (Cheng and Garg, 2014). The highest determination coefficient value is 0.934 in 2017 and the lowest is 0.567 in 2016 . Based on the regression equation above, shows the same trend of correlation for each year, where air temperature, wind speed and sunshine show a positive correlation, while relative humidity shows a negative correlation.

Determination coefficient value explains that, in 2013, the independent variable had an effect of $84.8 \%$ on the reference evapotranspiration (ETo) variable. in 2014, the independent variable had an effect of $84 \%$ on the reference variable evapotranspiration (ETo). In 2015, the independent variable had an effect of $85.8 \%$ on the reference variable evapotranspiration (ETo). In 2016, it was interpreted that the independent variable had an effect of $56.7 \%$ on the reference variable evapotranspiration (ETo). In 2017, the independent variable had an influence of $93.4 \%$ on the reference variable evapotranspiration (ETo).

Table 2 shows the average monthly weather parameters in each calculation of the amount of water loss in the batujai reservoir, which is adjusted for the availability of landsat 8 satellite images in calculating the area of water hyacinth cover. This data includes average temperature $\left({ }^{\circ} \mathrm{C}\right)$, relative humidity $(\%)$, wind speed $\left(\mathrm{m} \mathrm{s}^{-1}\right)$, sunshine $(\%)$ and reference evapotranspiration (ETo) was calculated based on data from weather stations using Cropwat 8 program of the year 2013- 2017.

Table 2. Average monthly weather and reference evapotranspiration (ETo) on Batujai Reservoir.

\begin{tabular}{|c|c|c|c|c|c|c|c|}
\hline No. & Date & $\mathrm{T}_{\mathrm{a}}$ & RH & $U_{2}$ & $\mathrm{~S}$ & ETo & ETc \\
\hline 1. & 25-Apr-13 & 27.1 & 82 & 1.5 & 61 & 4.02 & 4.42 \\
\hline 2. & 15-Aug-13 & 25.2 & 77 & 3.1 & 83 & 4.51 & 4.96 \\
\hline 3. & 3-Nov-13 & 27.3 & 83 & 2.1 & 57 & 4.42 & 4.86 \\
\hline 4. & 6-Jan-14 & 26.8 & 87 & 1.5 & 51 & 4.05 & 4.46 \\
\hline 5. & 14-Маy-14 & 27.2 & 82 & 0.5 & 86 & 3.71 & 4.55 \\
\hline 6. & 1-Jul-14 & 25.0 & 84 & 0.5 & 69 & 3.75 & 4.13 \\
\hline 7. & 21-Oct-14 & 27.0 & 77 & 3.1 & 91 & 5.60 & 6.16 \\
\hline 8. & 10-Feb-15 & 26.4 & 87 & 2.6 & 66 & 4.44 & 4.88 \\
\hline 9. & 15-Apr-15 & 27.0 & 86 & 2.6 & 59 & 3.84 & 4.22 \\
\hline 10. & 4-Jul-15 & 24.4 & 82 & 2.6 & 85 & 3.83 & 4.21 \\
\hline 11. & 5-Aug-15 & 24.6 & 80 & 3.6 & 83 & 4.31 & 4.74 \\
\hline 12. & $24-O c t-15$ & 26.9 & 78 & 3.6 & 91 & 5.57 & 6.13 \\
\hline 13. & 1-Apr-16 & 27.3 & 84 & 2.1 & 73 & 4.35 & 4.79 \\
\hline 14. & 3-Мay-16 & 27.5 & 83 & 1.5 & 76 & 4.03 & 4.43 \\
\hline 15. & 6-Jul-16 & 26.1 & 84 & 2.1 & 74 & 3.71 & 4.08 \\
\hline 16. & $10-O c t-16$ & 27.1 & 79 & 2.6 & 68 & 4.85 & 5.34 \\
\hline 17. & 20-Apr-17 & 27.1 & 83 & 1.5 & 77 & 4.44 & 4.88 \\
\hline 18. & 22-Мау-17 & 26.6 & 83 & 1.5 & 81 & 4.05 & 4.46 \\
\hline 19. & 26-Aug-17 & 25.4 & 81 & 2.1 & 80 & 4.17 & 4.59 \\
\hline
\end{tabular}

Note: $\mathrm{T}_{\mathrm{a}}=$ Air temperature $\left({ }^{\circ} \mathrm{C}\right), \mathrm{RH}=$ Relative humidity $(\%), U_{2}=$ Wind speed at 2 meter height $\left(\mathrm{m} \mathrm{s}^{-1}\right), \mathrm{S}=$ Sunshine $(\%), \mathrm{ETo}=$ Refrence evapotranspiration $\left(\mathrm{mm} \mathrm{day}^{-1}\right), \mathrm{ETc}=$ Crop evapotranspiration $\left(\mathrm{mm} \mathrm{day}^{-1}\right)$ 
Figure 9 shows the results of the calculation of the amount of water loss due to water hyacinth evapotranspiration, the highest water loss of
9,267.63 $\mathrm{m}^{3}$ day $^{-1}$ occurred on May 3, 2016 and the lowest of $236.54 \mathrm{~m}^{3}$ day $^{-1}$ occurred on October $21,2014$.

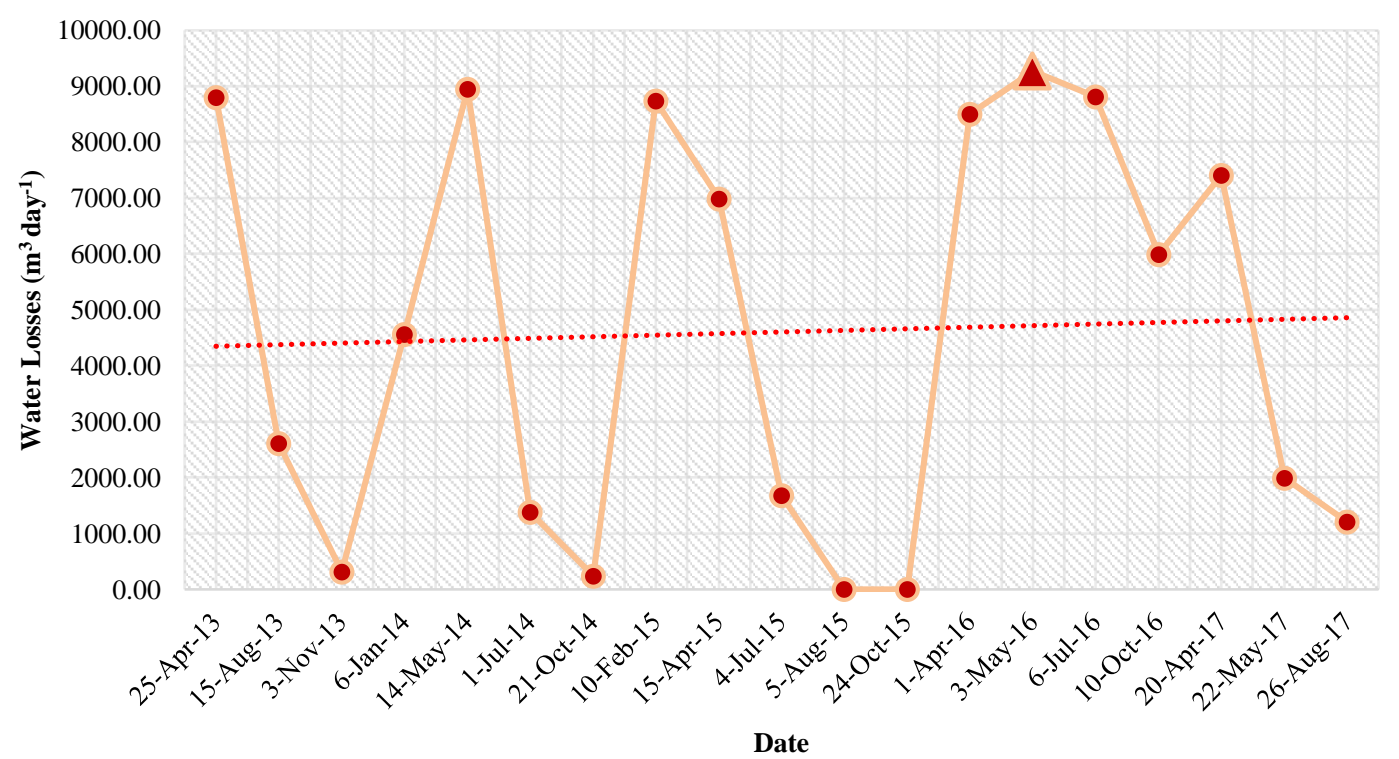

Figure 9. Water losses due to water hyacinth evapotranspiration in Batujai Reservior

The highest water loss occurred on May 3, 2016, this could occur due to the level of evapotranspiration and the extent of water hyacinth cover on the surface of the reservoir (Figure 2; Figure 6). Water loss through water hyacinth evapotranspiration with coverage area above $20 \%$, caused water losses above $8,000 \mathrm{~m}^{3}$ day $^{-1}$, which occurred in April 2013, April 2015, April 2016, February 2015, May 2014, May 2016 and July 2016. Based on these data, it is seen that in April during the 2013-2016 period there was a trend of water loss above $8,000 \mathrm{~m}^{3} \mathrm{day}^{-1}$ for three years. Water hyacinth cover with a coverage area ranging from $10 \%$ to $20 \%$ occurred in January 2014, October 2016 and April 2017, causing water losses ranging from $4,565.93 \mathrm{~m}^{3}$ day $^{-1}$ to $7,413.91 \mathrm{~m}^{3}$ day $^{-1}$.

The surface area of water hyacinth influences the amount of water loss, the low cover of water hyacinth has an impact on the amount of water loss is low, as well as extensive cover conditions have an impact on the amount of greater water loss (Arp et al., 2017; Ali and El-Din Khedr, 2018). The lowest water loss occurred on 21 October 2014, although the average evapotranspiration rate of water hyacinth in October was the highest at $6.16 \mathrm{~mm} \mathrm{day}^{-1}$ (Figure 8), however, the cover area of the water hyacinth was recorded as the lowest, which is around $1.29 \%$ of the total surface area of the reservoir with an area of 2,969,400 $\mathrm{m}^{2}$. Water hyacinth cover under $10 \%$, recorded occurred in August 2013, November 2013, July 2014, October 2014, July 2015, May 2017 and August 2017 with the amount of water loss ranging from $236.54 \mathrm{~m}^{3}$ day $^{-1}$ to $2,616.93 \mathrm{~m}^{3}$ day $^{-1}$.

\section{CONCLUSIONS}

Spatial distribution of water hyacinth can be detected and mapped accurately with an overall classification accuracy of $84.11 \%-97.04 \%$ using Landsat 8 data, with a kappa coefficient of $0.80-$ 0.96. The growth of water hyacinth in the Batujai Reservoir has caused many serious problems. Water loss through evapotranspiration of water hyacinth with a coverage area of more than $20 \%$, causes water loss above $8,000 \mathrm{~m}^{3}$ day $^{-1}$, which occurred in April 2013, April 2015, April 2016, February 2015, May 2014, May 2016 and July 2016, in those months it was seen that the amount of water loss was greater. Therefore, proper management and control is needed to suppress the growth of water hyacinth, in maintaining reservoir water storage capacity to support a system of sustainable agriculture in Central Lombok. 


\section{REFERENCES}

Abdullahi, J., \& Elkiran, G. (2017). Prediction of the future impact of climate change on reference evapotranspiration in Cyprus using artificial neural network. Procedia Computer Science, 120, 276-283. https://doi.org/ 10.1016/j.procs.2017.11.239

Achmad, F. (2011). Dampak pencemaran lingkungan kota praya terhadap kualitas air Waduk Batujai. Buletin of Environmental Geology, 21(2), 69-82. Retrieved from http://www.bgl.esdm.go.id/publication/index. php/dir/article_detail/576

Adeyemi, O., \& Osubor, C. C. (2016). Assessment of nutritional quality of water hyacinth leaf protein concentrate. Egyptian Journal of Aquatic Research, 42(3), 269-272. https://doi.org/10.1016/j.ejar.2016.08.002

Ali, Y. M., \& El-Din Khedr, I. S. (2018). Estimation of water losses through evapotranspiration of aquatic weeds in the Nile River (Case study: Rosetta Branch). Water Science, 32(2), 259-275. https://doi.org/ 10.1016/j.wsj.2018.08.002

Arp, R. S., Fraser, G. C., \& Hill, M. (2017). Quantifying the water savings benefit of water hyacinth (Eichhornia crassipes) control in the Vaalharts Irrigation Scheme / Vital Repository 7.0. Water SA, 43(1), 58-66. http:// dx.doi.org/10.4314/wsa.v43i1.09

Attermeyer, K., Flury, S., Jayakumar, R., Fiener, P., Steger, K., Arya, V., ... Premke, K. (2016). Invasive floating macrophytes reduce greenhouse gas emissions from a small tropical lake. Scientific Reports, 6, 1-10. https://doi.org/10.1038/srep20424

Berti, A., Tardivo, G., Chiaudani, A., Rech, F., \& Borin, M. (2014). Assessing reference evapotranspiration by the Hargreaves method in north-eastern Italy. Agricultural Water Management, 140, 20-25. https://doi.org/ 10.1016/j.agwat.2014.03.015

Bordoloi, S., Yamsani, S. K., Garg, A., Sreedeep, S., \& Borah, S. (2015). Study on the efficacy of harmful weed species Eicchornia crassipes for soil reinforcement. Ecological Engineering, 85, 218-222. https://doi.org/ 10.1016/j.ecoleng.2015.09.082
Čadro, S., Cherni-Čadro, S., Marković, M., \& Žurovec, J. (2018). A reference evapotranspiration map for Bosnia and Herzegovina. International Soil and Water Conservation Research. https://doi.org/ 10.1016/j.iswcr.2018.11.002

Cheng, C., \& Garg, G. (2014). Coefficient of determination for multiple measurement error models. Journal of Multivariate Analysis, 126, 137-152. https://doi.org/10.1016/j.jmva.2014. 01.006

Dooenboss, J., \& Pruitt, W. O. (1992). Crop water requirements (FAO Irrigation and Drainage Paper 24) (Revised 19). Rome: Food and Agriculture Organization of The United Nations.

Dube, T., Mutanga, O., Sibanda, M., Bangamwabo, V., \& Shoko, C. (2017). Testing the detection and discrimination potential of the new Landsat 8 satellite data on the challenging water hyacinth (Eichhornia crassipes) in freshwater ecosystems. Applied Geography, 84, 11-22. https://doi.org/10.1016/j.apgeog.2017.04.005

Elnmer, A., Khadr, M., Kanae, S., \& Tawfik, A. (2019). Mapping daily and seasonally evapotranspiration using remote sensing techniques over the Nile delta. Agricultural Water Management, 213(November 2017), 682-692. https://doi.org/10.1016/j.agwat.2018 .11 .009

Falamarzi, Y., Palizdan, N., Huang, Y. F., \& Lee, T. S. (2014). Estimating evapotranspiration from temperature and wind speed data using artificial and wavelet neural networks (WNNs). Agricultural Water Management, 140, 26-36. https://doi.org/10.1016/j.agwat. 2014.03.014

Farg, E., Arafat, S. M., Abd El-Wahed, M. S., \& El-Gindy, A. M. (2012). Estimation of Evapotranspiration ETc and Crop Coefficient $\mathrm{Kc}$ of Wheat, in south Nile Delta of Egypt Using integrated FAO-56 approach and remote sensing data. Egyptian Journal of Remote Sensing and Space Science, 15(1), 83-89. https://doi.org/10.1016/j.ejrs.2012.02.001

Gichuki, J., Omondi, R., Boera, P., Okorut, T., Matano, A. S., Jembe, T., \& Ofulla, A. (2012). Water hyacinth eichhornia crassipes (Mart.) 
solms-laubach dynamics and succession in the nyanza gulf of Lake Victoria (East Africa): Implications for water quality and biodiversity conservation. The Scientific World Journal, 2012. https://doi.org/10.1100/2012/106429

Güereña, D., Neufeldt, H., Berazneva, J., \& Duby, S. (2015). Water hyacinth control in Lake Victoria: Transforming an ecological catastrophe into economic, social, and environmental benefits. Sustainable Production and Consumption, 3(March), 5969. https://doi.org/10.1016/j.spc.2015.06.003

Güler, M. (2014). A comparison of different interpolation methods using the geographical information system for the production of reference evapotranspiration maps in Turkey. Journal of the Meteorological Society of Japan, 92(3), 227-240. https://doi.org/ 10.2151/jmsj.2014-303

Hou, L. gong, Zou, S. bing, Xiao, H. lang, \& Yang, Y. gang. (2013). Sensitivity of the reference evapotranspiration to key climatic variables during the growing season in the Ejina oasis northwest China. SpringerPlus, 2(1), 4-9. https://doi.org/10.1186/2193-18012-S1-S4

Indonesian National Institute of Aeronautics and Space. (2015). Pedoman Pemantauan Perubahan Luas Permukaan Air Danau Menggunakan Data Satelit Penginderaan Jauh (pp. 1-14). Indonesian National Institute of Aeronautics and Space. Retrieved from http://repository.lapan.go.id/index.php

Kalih, L. A. T. T. W. S., Septian, I. G. N., \& Sativa, D. Y. (2018). Makroinvertebrata sebagai Bioindikator Kualitas Perairan Waduk Batujai di Lombok Tengah. Biotropika Journal of Tropical Biology, 6(3), 103-107. https://doi.org/10.21776/ub.biotropika.2018.0 06.03.05

Khoshravesh, M., Sefidkouhi, M. A. G., \& Valipour, M. (2015). Estimation of reference evapotranspiration using multivariate fractional polynomial, Bayesian regression, and robust regression models in three arid environments. Applied Water Science, 7(4), 1911-1922. https://doi.org/10.1007/s13201015-0368-x

Laaboudi, A., Mouhouche, B., \& Draoui, B.
(2012). Neural network approach to reference evapotranspiration modeling from limited climatic data in arid regions. International Journal of Biometeorology, 56(5), 831-841. https://doi.org/10.1007/s00484-011-0485-7

Lingling, Z., Jun, X. I. A., Chong-yu, X. U., \& Zhonggen, W. (2013). Evapotranspiration estimation methods in hydrological models, 23(2010), 359-369. https://doi.org/10.1007/ s11442-013-1015-9

Longobardi, A., \& Villani, P. (2013). The Use of Micrometeorological Data to Identify Significant Variables in Evapotranspiration Modeling. Procedia Environmental Sciences, 19, 267-274. https://doi.org/10.1016/j.proenv. 2013.06.031

Manan, R. H. (2018). Kajian konsep perancangan lanskap green belt Waduk Batujai Kabupaten Lombok Tengah, Provinsi Nusa Tenggara Barat (Concept Studies of Landscape Design of Green Belt Batujai Reservoir, Central Lombok Regency,West Nusa Tenggara). In Seminar Nasional Kota Berkelanjutan (Vol. 1, p. 160). https://doi.org/10.25105/psnkb.v1i1. 2904

Marlin, D., Hill, M. P., \& Byrne, M. J. (2013). Interactions within pairs of biological control agents on water hyacinth, Eichhornia crassipes. Biological Control, 67(3), 483-490. https://doi.org/10.1016/j.biocontrol.2013.10.0 06

Ndimele, P., Jhonson, C. A. K., \& Anetekhai, M. (2011). The Invasive Aquatic Macrophyte, Water Hyacinth \{Eichhornia crassipes (Mart.) Solm-Laubach: Pontedericeae $\}$ : Problem and Prospects. Research Journal of Enviromental Sciences, 5(6), 509-520. https://doi.org/ 10.3923/rjes.2011.509.520

Opande, G. O., Onyango, J. C., \& Wagai, S. O. (2004). Lake Victoria: The water hyacinth (Eichhornia crassipes [MART.] SOLMS), its socio-economic effects, control measures and resurgence in the Winam gulf. Limnologica, 34(1-2), 105-109. https://doi.org/10.1016/ S0075-9511(04)80028-8

Osmond, R., \& Petroeschhevsky, A. (2013). Water hyacinth Control Modules Control options for water hyacinth (Eichhornia crassipes) in Australia. Australia: New South 
Wales Department of Primary Industries. Retrieved from https://www.dpi.nsw.gov.au/ __data/assets/pdf_file/0005/505706/water-

hyacinth-control-modules-full-accessible.pdf

Paca, V. H. da M., Davalos, G. E. S., Hessels, T. M., Moreira, D. M., Comair, G. F., \& Bastiaanssen, W. G. M. (2019). Ecological Processes The Spatial Variability of Actual Evapotranspiration Across the Amazon River Basin Based on Remote Sensing Models Validated with Flux-Towers. Ecological Processes, 8(6), 1-20. https://doi.org/ $10.1186 / \mathrm{s} 13717-019-0158-8$

Pandey, P. K., Dabral, P. P., \& Pandey, V. (2016). Evaluation of reference evapotranspiration methods for the northeastern region of India. International Soil and Water Conservation Research, 4(1), 52-63. https://doi.org/ 10.1016/j.iswcr.2016.02.003

Pokhrel, P., Ohgushi, K., \& Fujita, M. (2019). Impacts of future climate variability on hydrological processes in the upstream catchment of Kase River basin, Japan. Applied Water Science, 9(1), 1-10. https://doi.org/ 10.1007/s13201-019-0896-x

Rahim, A., \& Soeprobowati, T. R. (2019). Water Pollution Index of Batujai Reservoir, Central Lombok. Journal of Ecological Engineering, 20(3), 219-225. https://doi.org/10.12911/ $22998993 / 99822$

Rashed, A. A. (2014). Assessment of aquatic plants evapotranspiration for secondary agriculture drains (case study: Edfina drain, Egypt). Egyptian Journal of Aquatic Research, 40(2), 117-124. https://doi.org/10.1016/j.ejar. 2014.07.001

Sanmuga Priya, E., \& Senthamil Selvan, P. (2017). Water hyacinth (Eichhornia crassipes) - An efficient and economic adsorbent for textile effluent treatment - A review. Arabian Journal of Chemistry, 10, S3548-S3558. https://doi.org/10.1016/j.arabjc.2014.03.002

Saputra, I. P. (2018). Pengembangan Fungsi Kawasan Rth Waduk Batujai Sebagai Ruang Publik Di Kota Praya, Kabupaten Lombok Tengah, Ntb. Jurnal Pembangunan Wilayah \& Kota, 14(2), 143. https://doi.org/10.14710/ pwk.v14i2.19670

Sindhu, R., Binod, P., Pandey, A., Madhavan, A.,
Alphonsa, J. A., Vivek, N., Faraco, V. (2017). Water hyacinth a potential source for value addition: An overview. Bioresource Technology, 230, 152-162. https://doi.org/ 10.1016/j.biortech.2017.01.035

Singh Rawat, K., Kumar Singh, S., Bala, A., \& Szabó, S. (2019). Estimation of crop evapotranspiration through spatial distributed crop coefficient in a semi-arid environment. Agricultural Water Management, 213(June 2018), 922-933. https://doi.org/10.1016/ j.agwat.2018.12.002

Stan, F.-I., Neculau, G., Zaharia, L., IoanaToroimac, G., \& Mihalache, S. (2016). Study on the Evaporation and Evapotranspiration Measured on the Căldăruşani Lake (Romania). Procedia Environmental Sciences, 32, 281289. https://doi.org/10.1016/j.proenv.2016.03. 033

Su, W., Sun, Q., Xia, M., Yao, Z., \& Wen, Z. (2018). The Resource Utilization of Water Hyacinth (Eichhornia crassipes [Mart.] Solms) and Its Challenges. Resources, 7(3), 46. https://doi.org/10.3390/resources7030046

Surendran, U., Sushanth, C. M., Mammen, G., \& Joseph, E. J. (2015). Modelling the Crop Water Requirement Using FAO-CROPWAT and Assessment of Water Resources for Sustainable Water Resource Management: A Case Study in Palakkad District of Humid Tropical Kerala, India. In Aquatic Procedia (Vol. 4, pp. 1211-1219). Elsevier B.V. https://doi.org/10.1016/j.aqpro.2015.02.154

Suwargana, N. (2010). Luas danau berbasis datapenginderaan jauh di Danau Tempe, (4), $71-84$

Thamaga, K. H., \& Dube, T. (2018). Remote sensing of invasive water hyacinth (Eichhornia crassipes): A review on applications and challenges. Remote Sensing Applications: Society and Environment, 10(17), 36-46. https://doi.org/10.1016/j.rsase.2018.02.005

Tumbare, M. J. (2008). Managing Lake Kariba sustainably: Threats and challenges. Management of Environmental Quality: An International Journal, 19(6), 731-739. https://doi.org/10.1108/14777830810904948

Valipour, M. (2015). Temperature analysis of reference evapotranspiration models. 
Meteorological Applications, 22(3), 385-394. https://doi.org/10.1002/met.1465

Villamagna, A. M., \& Murphy, B. R. (2010). Ecological and socio-economic impacts of invasive water hyacinth (Eichhornia crassipes): A review. Freshwater Biology, 55(2), 282-298. https://doi.org/10.1111/ j.1365-2427.2009.02294.x

Wang, Z., \& Calderon, M. M. (2012). Environmental and economic analysis of application of water hyacinth for eutrophic water treatment coupled with biogas production. Journal of Environmental Management, 110, 246-253. https://doi.org/ 10.1016/j.jenvman.2012.06.031

Yan, S., Wang, Z., Liu, H., Zhang, Z., Zhang, J., $\&$ Zhang, Y. (2012). Large-scale utilization of water hyacinth for nutrient removal in Lake Dianchi in China: The effects on the water quality, macrozoobenthos and zooplankton. Chemosphere, 89(10), 1255-1261. https:// doi.org/10.1016/j.chemosphere.2012.08.001

Yang, Z., Liu, Q., \& Cui, B. (2011). Spatial distribution and temporal variation of reference evapotranspiration during 19612006 in the Yellow River Basin, China. Hydrological Sciences Journal, 56(6), 10151026. https://doi.org/10.1080/02626667.2011. 590810

Yasa, I. W., Bisri, M., Sholichin, M., \& Andawayanti, U. (2018). Hydrological drought index based on reservoir capacity Case study of Batujai dam in Lombok Island, West Nusa Tenggara, Indonesia. Journal Of Water And Land Development, 38(8-9), 155162. https://doi.org/10.2478/jwld-2018-0052
Yu, H., Shen, N., Yu, D., \& Liu, C. (2019). Clonal integration increases growth performance and expansion of Eichhornia crassipes in littoral zones: A simulation study. Environmental and Experimental Botany, 159(December 2018), 13-22. https://doi.org/10.1016/j.envexpbot. 2018.12.008

Yuliana, L., Sudiarta, I. W., \& Marzuki. (2015). Analisis Proyeksi Evapotranspirasi di Wilayah Nusa Tenggara Barat Menggunakan Skenario Proyeksi Perubahan Iklim (Analysis of evapotranspiration projection in the east west nusa using projection climate change scenario). Jurnal Kuanta, 1(1), 1-11. Retrieved from http://kuanta.unram.ac.id/ index.php/kuanta

Zhang, L., Liu, B., Karthikeyan, R., Singh, V., Fipps, G., Traore, S., Luo, Y. (2019). Assessment of spatiotemporal variability of reference evapotranspiration and controlling climate factors over decades in China using geospatial techniques. Agricultural Water Management, 213, 499-511. https://doi.org/ 10.1016/j.agwat.2018.09.037

Zhang, Z., Gong, Y., \& Wang, Z. (2018). Accessible remote sensing data based reference evapotranspiration estimation modelling. Agricultural Water Management, 210(November 2017), 59-69. https:// doi.org/10.1016/j.agwat.2018.07.039

Zhao, J., Xu, Z. X., Zuo, D. P., \& Wang, X. M. (2015). Temporal variations of reference evapotranspiration and its sensitivity to meteorological factors in Heihe River Basin, China. Water Science and Engineering, 8(1), 1-8. https://doi.org/10.1016/j.wse.2015.01. 004 